\title{
DISENTANGLING THE GEOGRAPHICAL LOGIC OF AIRBNB IN SWITZERLAND
}

\author{
Antoni Domènech, Blaise Larpin, Roland Schegg and Miriam Scaglione
}

With 4 figures and 5 tables

Received 29 July 2019 · Accepted 23 October 2019

\begin{abstract}
Summary: The unprecedented worldwide growth of Airbnb over the last decade deserves to be analysed from a geographical perspective so as to understand the underlying logic behind the spatial distribution of the accommodation offered on the platform. Multiple territorial and economic variables may influence this distribution. In this context, the article aims to analyse the spatial distribution of Airbnb in Switzerland and identify its determinants. Geographical Information Systems are used to analyse the geographical distribution of Airbnb listings, and Negative Binomial Models are applied to identify its determining factors. Results are particularly interesting as they highlight that Airbnb listings are mainly clustered geographically in specific areas of the country. The success of Airbnb as an accommodation supply platform has led to a concentration of Airbnb listings in areas of Switzerland where hotel supply is significant, but also in areas where there is a high presence of second homes and the potential for generating profit from the housing market is greater.
\end{abstract}

Zusammenfassung: Angesichts des beispiellosen weltweiten Wachstums von Airbnb in den zurückliegenden zehn Jahren, drängt sich aus geographischer Perspektive die Frage nach der zugrunde liegenden Logik hinter der räumlichen Verteilung der auf dieser Plattform angebotenen Unterkünfte auf. Mehrere territoriale und wirtschaftliche Variablen können diese Verteilung beeinflussen. In diesem Zusammenhang zielt der Artikel darauf ab, die räumliche Verteilung von Airbnb-Angeboten in der Schweiz zu analysieren und deren Determinanten zu identifizieren. Geographische Informationssysteme werden verwendet, um die geografische Verteilung der Airbnb-Angebote zu analysieren, und Negative Binomiale Modelle werden verwendet, um ihre bestimmenden Faktoren zu identifizieren. Die Ergebnisse sind besonders interessant, da sie zeigen, dass die Airbnb-Angebote hauptsächlich in bestimmten Gebieten des Landes gebündelt sind. Der Erfolg von Airbnb als Unterkunftsversorgungsplattform hat sowohl zu einer Konzentration der Airbnb-Angebote in Gebieten der Schweiz geführt, in denen die Hotelversorgung bedeutend ist, aber auch in Gebieten, in denen es eine hohe Präsenz von Zweitwohnungen gibt und das Gewinnpotenzial auf dem Wohnungsmarkt größer ist.

Keywords: Airbnb, short-term rental, GIS, Moran, Negative Binomial Model, Switzerland, tourism geography

\section{Introduction}

The Airbnb platform has experienced unprecedented growth since its creation in 2008. It has become the firm managing the highest number of tourist accommodation offers in the world, and holds a monopolistic position in multiple cities (JEFFERSONJONES 2014). In fact, the platform exceeds 6 million listings in more than 100,000 cities and 191 countries (https://news.airbnb.com/fast-facts/). Even though Airbnb argues that the proliferation of city listings is generating positive effects on the economy of local families and neighborhoods in general, criticism from the academia is starting to appear. Multiple researchers argue that this digital platform has changed the concept of sharing accommodation into a for-profit model (Hamari et al. 2015; FinCK and RANCHORD 2016; OSKAM and BOSWIJK 2016), and warn about the controversies caused by increased
Airbnb listings. Some studies analyse how Airbnb accommodation affects the rental price of residential housing units (Horn and Merante 2017), or how it has become a vehicle for gentrification and processes of displacement (Cócola Gant 2016; GravariBARBAS and GUINAND 2017; WACHSMUTH and WEISLER 2018; IoAnnides et al. 2018). Additionally, Airbnb has also been earmarked as an unfair competitor vis-à-vis other tourist accommodation (GUTTENTAG 2015; Osкам and Boswijk 2016) and, therefore, the impact of the presence of Airbnb accommodation on the price of regulated tourist accommodation has also been analysed (Boros et al. 2018).

Spatial analysis techniques have been used in several studies to determine the impacts of Airbnb accommodation. Although most of these researches are focused on urban areas (GUNTER and ÖNDER 2017; Gutiérrez et al. 2017; QuATtrone et al. 2016), a few, selective studies can be found on different territorial 
scales of analysis. Hence, there are also comparative studies on the spatial distribution of the Airbnb accommodation supply across European cities (COYLE and Yu-Cheong 2017; Adamiak 2018), between countries (ABDAR and YeN 2017), and within countries (ADAMiAK et al. 2019).

In this context, the article aims to expand the existing literature on the spatial distribution of Airbnb with a municipal-level analysis covering a whole country. Specifically, it intends identifying the underlying geographical logic behind the distribution of Airbnb listings in Switzerland. The analysis of the Airbnb spatial distribution in this country is particularly interesting due to the adaptations and shifts that the Swiss tourism sector has experienced over recent decades. Associating the Alps with Switzerland ensures dominance in terms of alpine tourism (Tissot 2002), which has boosted tourism as one of the most important parts of the country's economy (NICOD et al. 2007). For instance, in 2018, the total revenue generated by Swiss tourism totalled CHF 44.7 billion (Swiss Tourism Federation 2019). Despite this, over the last 30 years hotel stock has been declining in numbers ${ }^{1}$, with a parallel increase, since the 1960s, in other types of accommodation, such as second homes or holiday dwellings. This restructuring of the tourism accommodation sector has been led by changes in global consumption patterns, together with currency exchange effects and, obviously, a development model based on "construction tourism" rather than "service tourism". Traditionally, the greatest concern about holiday homes in Switzerland was the so-called "cold beds" phenomenon, defined as the controversy generated by the increase in the construction of second homes and the small proportion of these offered as shortterm rentals (NiCOD et al. 2007; Clivaz 2013). On March 11, 2012, the addition of a new Article (75b) into the Swiss Constitution marked a turning point in the development of Swiss resorts and in the structure of the tourism accommodation sector. This new article stated that "no more than 20 per cent of total stock of residential units [...] in any commune may be used as second homes"'2). From this moment on, a shift occurred from a real estate activity model towards an accommodation supply model (CLIVAZ 2013). Consequently, the appearance of Airbnb as a

1) The number of hotels has declined from 6,800 in 1989 (NICOD et al. 2007) to 4,765 in 2018 (SWISS TOURISM FEDERATION 2019).

2) https://www.admin.ch/opc/en/classified-compi-lation/ 19995395/index.html\#a75 platform that markets all types of accommodation could have been a great opportunity for advertising holiday short-term rentals. In this context, very little is known about both the spatial distribution of the accommodation offered on this platform and the association with other territorial and tourist variables. Therefore, this article aims, on the one hand, to analyse the spatial distribution of Airbnb listings to detect whether they are spatially clustered in certain areas of the country. On the other hand, it attempts to detect the economic and territorial factors that could determine this spatial distribution. Accordingly, the empirical analysis of this article consists of two stages. Firstly, geostatistical techniques are used to detect the areas where the concentration of Airbnb is higher. Secondly, a regression analysis is implemented to identify the determinants of the Airbnb spatial distribution.

The remaining part of the article is structured as follows: first, a literature review is presented. Multiple research hypotheses emerge from the literature review, which are tested in this study. In the next section, further information on the data used and the methods applied are explained. Then, results of the geostatistics and regression analysis are exposed. And finally, the discussion and conclusion are presented.

\section{Literature review}

Sharing or exchanging resources, products, assets or abilities between individuals or communities has always been part of our society (ZeRvas et al. 2017). However, the emergence of digital platforms acting as online markets has increased the chances of exchanging products and services between individuals, without depending on the supply from centralised institutions. This economic model of the sharing economy, also known as peer-to-peer (P2P) economy, has been successful in multiple services offered through online platforms in diverse economic fields, including transportation (Uber, BlaBlaCar), the sale of second-hand articles (Wallapop, eBay) and the tourist accommodation sector (Airbnb, HomeAway).

In this latter sector, Airbnb has succeeded worldwide. It began with the idea of renting excess space in private homes as a way to generate extra income. However, a decade later, it has evolved towards platform professionalization and has become an actual alternative to traditional accommodation (LARPIN et al. 2019). Even though from the point of view of supply it is difficult to compare Airbnb and hotels, due 
to the different nature of the owners, from the point of view of demand, consumers regard Airbnb as an alternative to hotels (HEO et al. 2019). In fact, with regards to the general public, Airbnb has facilitated and increased access to contact between tourists and owners offering holiday homes and apartments. As a result, a win-win relationship evolves between owners and tourists, as the owner can have the house occupied during more days per year and the tourist can enjoy more reasonable prices than staying in a hotel (GUNTER 2018), and more intimacy and privacy when the rental is an entire apartment or home (NICOD et al. 2007). This change in travel behaviour leads to an increase in the economic interests of multi-hosts to offer accommodation through the platform in very dynamic and popular tourist areas where the possibilities of renting accommodation are higher (Bulchand-Gidumal et al. 2019). In this regard, real estate agencies or similar companies see Airbnb as a good way to develop and expand their business in areas where the potential for generating new profits and maximising revenues within the housing market are greater (LEE 2016; WACHSMUTH and WeISLER 2018; YrIGOY 2019). Along these lines, a study conducted in the Canary Islands revealed that those areas with higher accommodation prices offered on Airbnb are also the territories with a higher Airbnb supply (Eugenio-Martin et al. 2019).

The spatial diffusion of Airbnb can affect housing and tourism markets on a local, regional, national or global scale. Researches analysing the effects of Airbnb on the housing market have shown that Airbnb has a causal impact on the rental market, and therefore on the accessibility to housing. In North America, results from two researches developed in Boston (Horn and Merante 2017) and Los Angeles (LEE 2016) show that Airbnb density increases rents in the neighbourhoods in both cities. A study developed in New York City (Wachsmuth and Weisler 2018) explains how a rent gap is unevenly generated in certain areas within the city by substituting long-term rentals for short-term rentals. Likewise, in the European context, Airbnb listings have tended to concentrate in neighbourhoods that have undergone processes of commercial and tourist gentrification (Roelofsen 2018). And not only this, but also contributing to the "collective displacement" process (Cócola GANT 2016) derived from the conversion of long-term housing into short-term tourist rentals. The increase in tourists in specific city areas attracts the interest of owners and companies who want to profit from the situation. Hence, substituting residential uses of housing for tourist accommodation is a fast way to introduce a new potential investment flow into the housing market. This leads to a shortage of housing for locals and an increase in prices. Hence, gentrification processes have been identified in researches developed in the European cities of Barcelona (Cócola Gant 2016), Berlin (Novy 2017), Palma de Mallorca (YrigoY 2017) and Utrecht (IOANNIDES et al. 2018).

Airbnb has also been earmarked as an unfair competitor in other types of tourist accommodation (Guttentag 2015; Oskam and Boswijk 2016) and, therefore, several researches have analysed the impact of the presence of Airbnb accommodation on the hotel industry. However, due to the limitations on data availability for running temporally extensive and geographically completed analyses, it is difficult to obtain conclusive results. In terms of geographical distribution, GuTIÉRREZ et al. (2017) found a centre-periphery pattern of Airbnb distribution in Barcelona, where it acts as a hotel industry competitor in central areas, and as an accommodation complement in peripheral areas. Similarly, a study developed in eight US urban areas by QUATTRONE et al. (2018) showed that Airbnb tends to cluster in central neighbourhoods and also in areas, not necessarily in the city centres, but occupied by creative classes. However, the spatial distribution of the Airbnb location has an effect on hotel performance. In this regard, researches with contradictory results have emerged during recent years. For instance, a research developed in Korea by CHOI et al. (2015) found that Airbnb does not influence hotel performance. Meanwhile, research carried out by DoGru et al. (2018) in ten major US hotel markets for the period $2008-2017$ has shown that the increase in the Airbnb supply negatively affects room revenues, average daily rates and occupancy rates.

Most of these researches have been carried out on an urban scale, although a few studies have been developed on different territorial scales, which are also particularly important for disentangling the diffusion patterns regarding this kind of phenomena. Hence, comparative studies on the spatial distribution of the Airbnb supply across European cities (Adamiak 2018), between countries (ABDAR and YEN, 2017) and within countries (ADAmiak et al. 2019; CESARINI and NeChitA 2017; Strommen-Bakhtiar and Vinogradov 2019) have been contributing recently to this research. In this context, the article aims to expand the existent literature by analysing, on a municipal-basis, the spatial distribution of Airbnb listings in Switzerland and identifying the determinants of the growth of this type of accommodation so as to detect potential impacts on the housing and tourist markets. 
Moreover, the case of Switzerland is particularly relevant as its tourism model has been based for decades on "construction tourism" rather than "service tourism" (Clivaz 2013). The construction of second homes in alpine regions has boosted the tourism sector since the 1960 s, with its corresponding externalities in the economic, social and environmental spheres. Some of the externalities generated by this real estate activity were the important difficulties for the local residents to find housing (due to the rising prices fuelled by the demand for second homes) or the fragmentation of the landscape and the urban sprawl. However, the greatest concern about holiday homes in Switzerland was the controversy generated by the increase in the construction of second homes and the small proportion of these offered as short-term rentals (Nicod et al. 2007; Clivaz 2013). Hence, for a long time the land was more valuable for its exchange value than its use. As a consequence, currently there are around 700,000 second homes (about 16\% of total housing stock) in the country, more than $50 \%$ of which are in the alpine area which, at the same time, is the less densely populated area. In many of the municipalities in these alpine regions, second homes represent more than half of the housing stock (CLIVAz 2013). The approval of the initiative on second homes in 2012 (Article 75b of the Swiss Constitution), which virtually cuts the construction of second homes in regions where $20 \%$ of the total housing stock was exceeded, meant adapting to the new reality from the perspective of holiday home owners and real estate promoters. NiCOD et al. (2007) concluded, from their analysis on the situation of the self-catering accommodation in Switzerland, that there was a need for greater cohesion and visibility within the sector in order to increase the profits from this type of accommodation. They, furthermore, stated that Internet could be the key to achieving these necessary aims. In fact, their diagnosis was potentially right, as the appearance of Airbnb as a platform that markets and integrates the "informal" accommodation supply could have been a great opportunity for advertising short-term holiday rentals with the advent of the new Constitution article.

In this context, this study will provide interesting insights into both the spatial distribution of the accommodation offered on Airbnb in Switzerland and the association with territorial and tourist variables. Concretely, multiple research hypotheses emerge from the literature review presented, which will be tested in this research. On the one hand, and in connection with the first research objective, it is hypothesized that Airbnb listings could be clustered in specific areas of the country as, according to the first law of geography, all territories are linked to each other, but those that are nearer are more similar (TOBLER 1970). On the other hand, and in connection with the second research objective, five hypotheses are formulated about the possible factors influencing the territorial logic of the Airbnb supply:

1. Airbnb concentrates in areas attractive to tourists and with pre-established tertiary activity in general, particularly in the tourism sector. Hence, there is an association between Airbnb rentals and hotel accommodation. This correlation has been previously demonstrated on different territorial scales: at country-level (ADAMIAK et al. 2019), at regional and tourism destination level (Eugenio-Martin et al. 2019), and at city-level (Gutiérrez et al. 2017).

2. A higher concentration of Airbnb accommodation is found in larger cities and densely populated areas which, at the same time, are also important tourism destinations and business areas where Airbnb can complement the existent hotel supply (ADAmiak et al. 2019; Eugenio-Martin et al. 2019).

3. The Airbnb offer is located in places close to ski resorts, which, in addition to major cities, are main leisure tourism destinations in Switzerland (Tissot 2002; Nicod et al. 2007). Proximity to the mountain resorts is associated not only with the former high development construction ratio of second homes in these Swiss alpine areas, but also with the need for these territories to adapt to the new scenario imposed by the legislation on second homes.

4. The location of Airbnb rentals is determined by the number of second homes. This has been previously showcased in the context of Spain (ADAmiak et al. 2019). However, in the case of Switzerland it is particularly relevant, as the transition process from the "model of real estate activity and the sale of second homes" to the promotion of an "accommodation model" (CLIVAz 2013) could have brought an increase in the marketing of holiday homes through Airbnb.

5. Those areas with higher potential for generating new profits in the housing market will have a greater proportion of short-term rentals offered by multi-hosts. This hypothesis is in line with the studies that have highlighted the fact that the emergence of Airbnb should be analysed as a new way to maximise revenues within the housing market (LeE 2016; Wachsmuth and Weisler 2018; YRIGOY 2018). 


\section{Methodology}

\subsection{Data gathering}

Different variables are used in this article to fulfil the research objectives (see Tab. 1). Data on the Airbnb listings in Switzerland has been provided by the Valais Tourism Observatory. They used the Airbnb API and developed a script to download all the data related to the active Airbnb listings in January 2018. The dataset contains 32,761 Airbnb listings (see Fig. 1), with information on the host identifier, the number of rooms per listing, as well as the capacity, beds and price. According to an official report by Airbnb on the situation of the platform in Switzerland from November 2017 and November 2018 (Airbnb's Travel Report Switzerland 2018), the number of active listings was around 35,800 (Fig 2). Hence, our dataset is reliable and representative, as it contains $91.5 \%$ of the listings available on the platform.

With the hosts "id" number we have calculated the percentage of listings offered by multihosts. The existent literature has tended to define the multi-hosts as those owners with a minimum number of listings offered on the platform, ranged between 2 (BulCHAND-Gidumal et al. 2019) and 10 (LAR PIN et al. 2019). After an exploratory analysis of our dataset, we observed that there is a total of 22,497 hosts and most of them (94\%) own just one listing in Airbnb. These individual hosts made up $71 \%$ of the total offer on the platform. Meanwhile, hosts owning 2 or more short-term rentals on the platform (1,338 hosts) totalled 29\% of the Airbnb listings. Out of these multi-hosts, 380 of them stood out with more than 5 properties offered on the platform, accumulating $20 \%$

Tab. 1: Variables used in this article

\begin{tabular}{|c|c|c|}
\hline Variable & Description & Source \\
\hline Airbnb listings & Number of Airbnb listings per municipality & $\begin{array}{l}\text { Valais Tourism Observatory (Airbnb } \\
\mathrm{API} \text { ) }\end{array}$ \\
\hline Airbnb listings per 1.000 homes & $\begin{array}{l}\text { Number of Airbnb listings per municipality } \\
\text { standardised per } 1,000 \text { homes }\end{array}$ & $\begin{array}{l}\text { Own elaboration by means of data } \\
\text { from the Valais Tourism Observatory } \\
\text { and the Federal Office for Spatial } \\
\text { Development of Switzerland }\end{array}$ \\
\hline $\begin{array}{l}\text { Airbnb listings (\%) offered by } \\
\text { multi-hosts }\end{array}$ & $\begin{array}{l}\text { Percentage of Airbnb listings offered by } \\
\text { multi-hosts ( }>5 \text { listings) per municipality }\end{array}$ & $\begin{array}{l}\text { Own elaboration by means of data } \\
\text { from the Valais Tourism Observatory }\end{array}$ \\
\hline Second homes & Number of second homes per municipality & $\begin{array}{l}\text { Federal Office for Spatial } \\
\text { Development of Switzerland }\end{array}$ \\
\hline Distance to ski resorts & $\begin{array}{l}\text { Proximity of each municipality to the nearest } \\
\text { ski resort ( } \mathrm{km} \text { in Euclidean distance) }\end{array}$ & Own elaboration \\
\hline Hotels & $\begin{array}{l}\text { 1. Number of hotels per municipality } \\
\text { 2. Average number of rooms per hotel per } \\
\text { municipality }\end{array}$ & $\begin{array}{l}\text { Federal Office for Spatial } \\
\text { Development of Switzerland }\end{array}$ \\
\hline $\begin{array}{l}\text { Geographical levels of } \\
\text { Switzerland }\end{array}$ & $\begin{array}{l}\text { 1. Municipality belonging to a densely } \\
\text { populated area } \\
\text { 2. Municipality belonging to an } \\
\text { intermediate density area } \\
\text { 3. Municipality belonging to a thinly } \\
\text { populated area }\end{array}$ & $\begin{array}{l}\text { Federal Statistics Office of } \\
\text { Switzerland: Document "Limites } \\
\text { communales généralisées de la } \\
\text { Suisse" }\end{array}$ \\
\hline $\begin{array}{l}\text { Employed population by } \\
\text { economic sectors of activity }(\%) \\
\text { per municipality }\end{array}$ & $\begin{array}{l}\text { 1. Percentage of employed population in } \\
\text { the primary economic sector of activity } \\
\text { 2. Percentage of employed population } \\
\text { in the secondary economic sector of } \\
\text { activity } \\
\text { 3. Percentage of employed population in } \\
\text { the tertiary economic sector of activity }\end{array}$ & $\begin{array}{l}\text { Federal Office for Spatial } \\
\text { Development of Switzerland }\end{array}$ \\
\hline
\end{tabular}



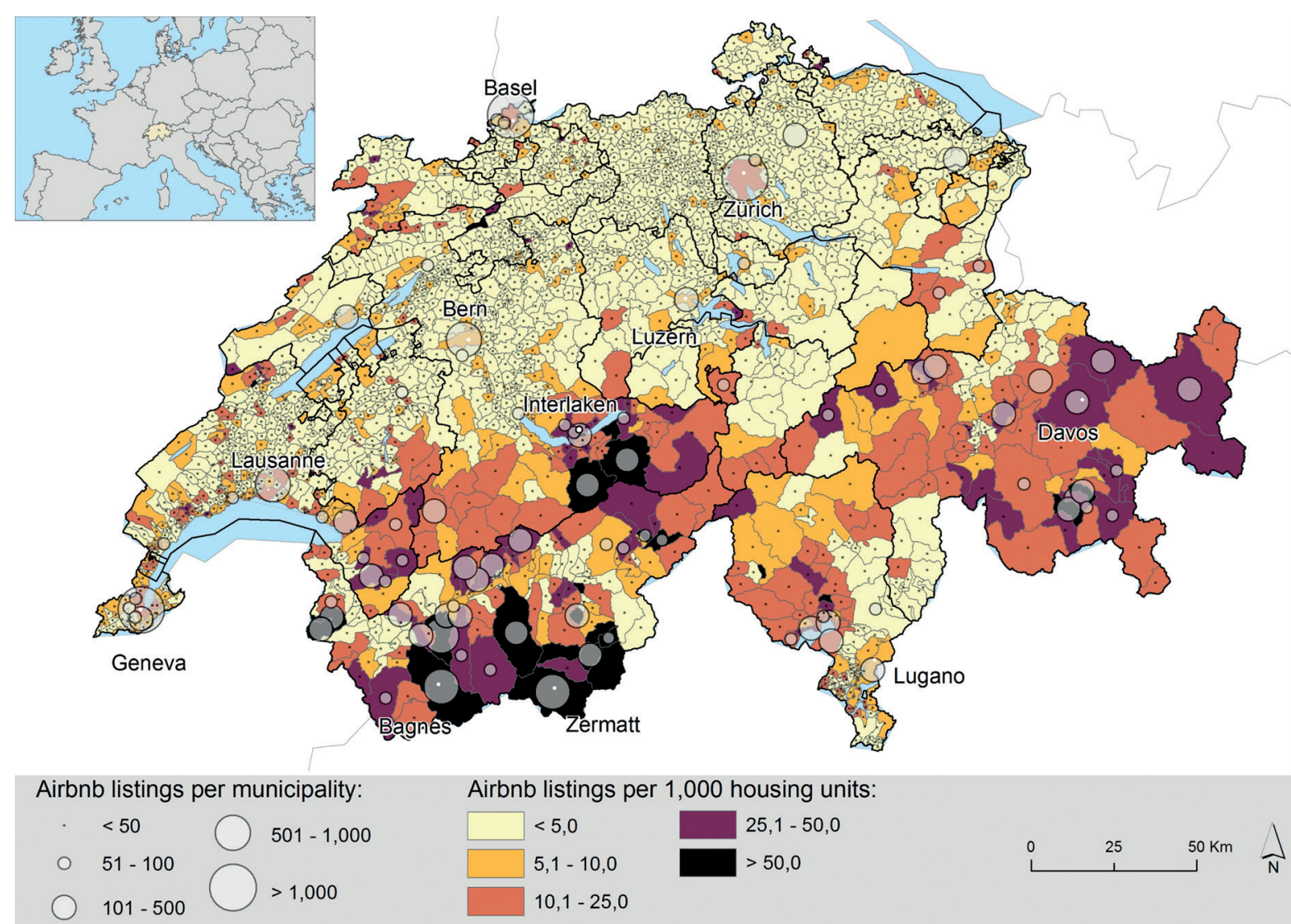

Fig. 1: Number of Airbnb listings per municipality in absolute and relative values (per 1,000 housing units)

of the supply. Hence, we decided to fix the intermediate number of 5 listings offered on the platform as the threshold to define a multi-host. In this sense, we are focusing on the more professionalized hosts who look for profiteering and maximising benefits from territories with greater potential for revenue.

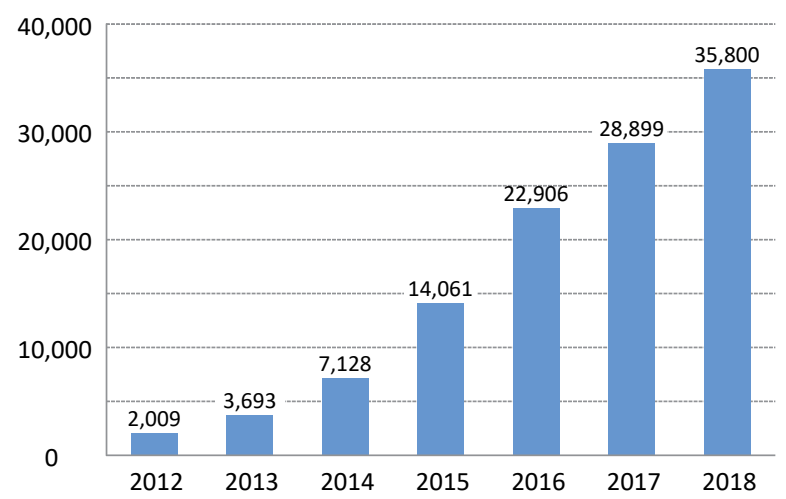

Fig. 2: Evolution of Airbnb listings during the period 20122018. Source: Own elaboration from data extracted from Airbnb's Travel Report Switzerland 2018
On the other hand, data has been gathered from other variables which could explain Airbnb's spatial distribution across the country. The hotel indicator shows the level of potential tourism attraction in the municipalities. In particular, the variables considered are the number of hotels, as well as the average hotel rooms offered per hotel. The number of second homes has also been gathered, as it indicates the municipalities' higher potential for offering homes on the Airbnb platform. We hypothesize that the higher the number of second homes, the higher the probability of listing them as tourist accommodation. Moreover, the distance to the nearest ski resort has been calculated for each municipality. This is a key variable because, apart from major cities, the ski resorts are leading leisure destinations in Switzerland. Therefore, data has also been gathered on the economic sectors where the population is employed, and the percentage of employed population in the three sectors has been calculated. Finally, the classification according to the population density has also been used. 


\subsection{Methods}

In order to respond to the first research objective (on Airbnb spatial clustering in certain regions of the country), the Local Moran's spatial autocorrelation indicator (ANSELIN 1995) has been applied. The variable introduced to develop the analysis was the number of Airbnb listings standardised per 1,000 homes. The variable has been normalised in order to ensure comparability between municipalities of different demographic size. The indicator can be defined as follows:

$$
I_{i}=\frac{\left(X_{i-\mu}\right)}{m_{0}} \sum_{j=1, j \neq i}^{n} \omega_{i, j}\left(\chi_{j}-\mu\right)^{2}
$$

where $\chi_{i}$ is an attribute for feature $i, \mu$ is the mean of the corresponding attribute, $\omega_{\mathrm{i}, \mathrm{j}}$ is the spatial weight between feature $i$ and $j, n$ is the number of features (in this study the municipal administrative areas), and:

$$
m_{0}=\frac{\sum_{j=1, j \neq i}^{n} \omega_{i, j}\left(\chi_{j}-\mu\right)^{2}}{\mathrm{n}-1}
$$

According to the first law of geography, "everything is related to everything else, but near things are more related than distant things" (Tobler 1970, 236). Therefore, it is hypothesized that those municipalities with higher Airbnb values per 1,000 homes will be clustered in certain areas of Switzerland. The Local Moran's indicator will identify areas made up of municipalities with high values of Airbnb listings (hot spots), as well as areas with low values (cold spots) and statistically significant spatial outliers (at least at $\mathrm{p}<0.05$ ). The parameter for conceptualizing spatial relationships between municipalities was a threshold metric distance of $20.5 \mathrm{~km}$, which ensures that all the entities have a minimum of one neighbour. Regression analysis has been carried out to fulfil the second research objective (to identify the determinants of the spatial distribution of Airbnb listings). The econometric methodology best suited to the characteristics of our dependent variable (i.e., number of Airbnb listings by municipality) is count data models (CDM). This is because the dependent variable has a Poisson distribution (see Fig. 3) rather than a normal one, which means it is inappropriate to use alternative estimation procedures such as OLS.

CDM are especially useful when the events being analysed are recorded at a highly disaggregated territorial level. In our study, the number of spa- tial units is large (i.e., 2.222 Swiss municipalities in January 2018) and in some areas zero Airbnb listings are reported, a situation known as the 'zero problem'. However, CDM can deal with this situation. The existence of such zeroes is relevant because municipalities with no Airbnb listings provide relevant insight into the Airbnb phenomena, since the values of the independent variables in these municipalities can help to explain why there are no Airbnb listings there. In fact, a total of $26 \%$ Swiss municipalities have no Airbnb listing (see Tab. 2) and applying the Moran's indicator has shown that, effectively, there is a spatial clustering of Airbnb listings. Hence, these results suggest using a negative binomial model (NBM), since overdispersion and zero problems can easily be solved using this method. Additionally, results from AIC and BIC support using the NBM instead of the Poisson model. With a view to the general features of this estimation procedure, NBM assumes between-subject heterogeneity and that the process is the same for both zero and non-zero counts.

Two general non-linear NBM have been applied, taking the municipalities as a statistical unit and the number of Airbnb listings per municipality as dependent variable ( $Y$ ) (McCullagh and Nelder 1989, 373). The indicators set out in Table 3, have been included as explanatory variables. Correlation among them has been checked (see Tab. 3) and multicollinearity (CAMERON and TRIVEDI 2010) has also been controlled with satisfactorily low values (see results of the variance inflation factors -VIF- in Tab. 5). Although no major problems of correlation among explanatory variables have been detected, a high associa-

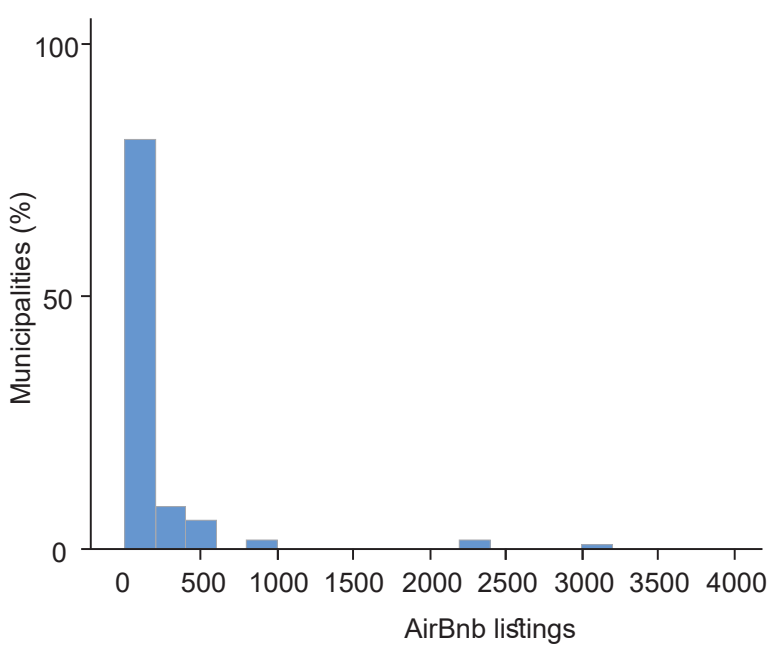

Fig. 3: Histogram of the dependent variable (Airbnb listings) 
Tab. 2: Descriptive statistics of the dependent variable segmented by interval size of the municipalities

\begin{tabular}{|c|c|c|c|c|c|c|c|}
\hline Population interval & $\begin{array}{r}\text { Number of } \\
\text { municipalities }\end{array}$ & $\begin{array}{r}\text { Number } \\
\text { of Airbnb } \\
\text { listings }\end{array}$ & Min. & Max. & Average & Std. Dev. & $\%$ zeroes \\
\hline$<1,000$ & 803 & 2,173 & 0 & 118 & 2.7 & 7.4 & 47.8 \\
\hline $1,000-5,000$ & 1,032 & 9,765 & 0 & 432 & 9.5 & 29.4 & 18.7 \\
\hline $5,000-10,000$ & 234 & 5,261 & 0 & 931 & 22.5 & 83.8 & 3.4 \\
\hline $10,000-25,000$ & 122 & 3,784 & 2 & 467 & 31.0 & 58.8 & 0 \\
\hline$>25,000$ & 31 & 11,774 & 7 & 3,086 & 379.8 & 763.2 & 0 \\
\hline Total & 2,222 & 32,757 & 0 & 3,086 & 14.7 & 105.6 & $26.30 \%$ \\
\hline
\end{tabular}

Tab. 3: Correlation among explanatory variables

\begin{tabular}{|c|c|c|c|c|c|c|c|c|c|c|c|}
\hline & [1] & [2] & [3] & [4] & [5] & [6] & [7] & [8] & [9] & [10] & [11] \\
\hline $\begin{array}{l}\text { [1] Distance to nearest ski } \\
\text { resort }(\mathrm{km})\end{array}$ & 1.000 & & & & & & & & & & \\
\hline [2] Second homes & $-0.118^{* *}$ & 1.000 & & & & & & & & & \\
\hline $\begin{array}{l}\text { [3] Airbnb listings offered } \\
\text { per multi-hosts }\end{array}$ & $-0.160^{* *}$ & $0.293 * *$ & 1.000 & & & & & & & & \\
\hline [4] Number of hotels & $-0.173^{* *}$ & $0.746 * *$ & $0.318^{* *}$ & 1.000 & & & & & & & \\
\hline $\begin{array}{l}\text { [5] Average hotel rooms } \\
\text { per hotel }\end{array}$ & $-0.068^{* *}$ & $0.356^{* *}$ & $0.173^{* *}$ & $0.340 * *$ & 1.000 & & & & & & \\
\hline $\begin{array}{l}\text { [6] Employed population } \\
\text { in the } 1^{\text {st }} \text { sector }\end{array}$ & $-0.067 * *$ & $-0.208 * *$ & $-0.076 * *$ & $-0.151 * *$ & $-0.290^{* *}$ & 1.000 & & & & & \\
\hline $\begin{array}{l}\text { [7] Employed population } \\
\text { in the } 2^{\text {nd }} \text { sector }\end{array}$ & $0.051 *$ & $-0.098 * *$ & $-0.055^{*}$ & $-0.099 * *$ & $-0.110^{* *}$ & $-0.339 * *$ & 1.000 & & & & \\
\hline $\begin{array}{l}\text { [8] Employed population } \\
\text { in the } 3^{\text {rd }} \text { sector }\end{array}$ & 0.025 & $0.271^{* *}$ & $0.112^{* *}$ & $0.221 * *$ & $0.356^{* *}$ & $-0.631 * *$ & $-0.501 * *$ & 1.000 & & & \\
\hline [9] Thinly populated & $-0.120 * *$ & $-0.163^{* *}$ & -0.014 & $-0.092 * *$ & $-0.222 * *$ & $0.553 * *$ & $-0.108 * *$ & $-0.416^{* *}$ & 1.000 & & \\
\hline $\begin{array}{l}\text { [10] Intermediately } \\
\text { populated }\end{array}$ & $0.057 * *$ & -0.028 & 0.004 & -0.015 & $-0.044^{*}$ & $-0.241 * *$ & $0.137 * *$ & $0.110^{* *}$ & $-0.620 * *$ & 1.000 & \\
\hline [11] Densely populated & $0.084 * *$ & $0.227 * *$ & 0.012 & $0.128^{* *}$ & $0.315^{* *}$ & $-0.414^{* *}$ & -0.015 & $0.387 * *$ & $-0.553 * *$ & $-0.311 * *$ & 1.000 \\
\hline
\end{tabular}

tion between the number of second homes and the number of hotels per municipality has been identified. In accordance, two regression analyses have been implemented. In each of them, one of these highly correlated variables has been excluded. Hence, we ensure that we correctly capture the effect of each variable on the dependent variable and, furthermore, we can see which model presents better goodness of fit indicators. The models are defined as follows:

$\log (\mathrm{E}(\mathbf{Y}))=\beta_{0}+\beta^{\prime} \mathbf{x} \quad \mathbf{Y}: \mathrm{NB}(\mu(\mathbf{x}), \quad k)$ where $\mathrm{E}(\mathbf{Y} \mid \mathbf{x})=\mu(\mathbf{x})$ and $\mathrm{V}(\mathbf{Y} \mid \mathbf{x})=\mu(\mathbf{x})+k \mu(\mathbf{x})^{2}$

where $\beta$ is the regression coefficient vector and $x$ the municipalities covariates and $\beta_{0}$ the intercept

\section{Results}

\subsection{Spatial clustering of Airbnb listings in Swit- zerland}

Applying the Local Moran's spatial autocorrelation indicator has supported the first hypothesis in this article, regarding the spatial clustering of Airbnb listings in specific areas of Switzerland. Particularly, a prominent and outstanding division has been identified between the northern and southern parts of the country. ${ }^{3)}$ Figure 4 clearly shows where the clus-

3) The implementation of the Local Moran's indicator with GeoDa software allows calculating the Moran's Global Indicator, at the same time, which shows whether clustering exists or not. 
ters identified by the Local Moran's indicator are mapped, with low value Airbnb listings per 1,000 housing units mainly concentrated in the northern half of Switzerland (blue), and high values clustered particularly in the southern area (red).

In the northern part of the country there are some significant outliers with high values of Airbnb listings per 1,000 housing units, surrounded by mu-
4 , it is made up of 41 municipalities to the south of the Bern canton (26.3 Airbnb listings per 1,000 homes), a total of 83 municipalities in the Valais canton (37.7) and 36 municipalities in the Ticino canton (14.6).

Important tourist hotspots such as Lauterbrunnen (85.9) and Interlaken (59.2) in the Bern canton, Bagnes (90.6) and Zermatt (67.9) in

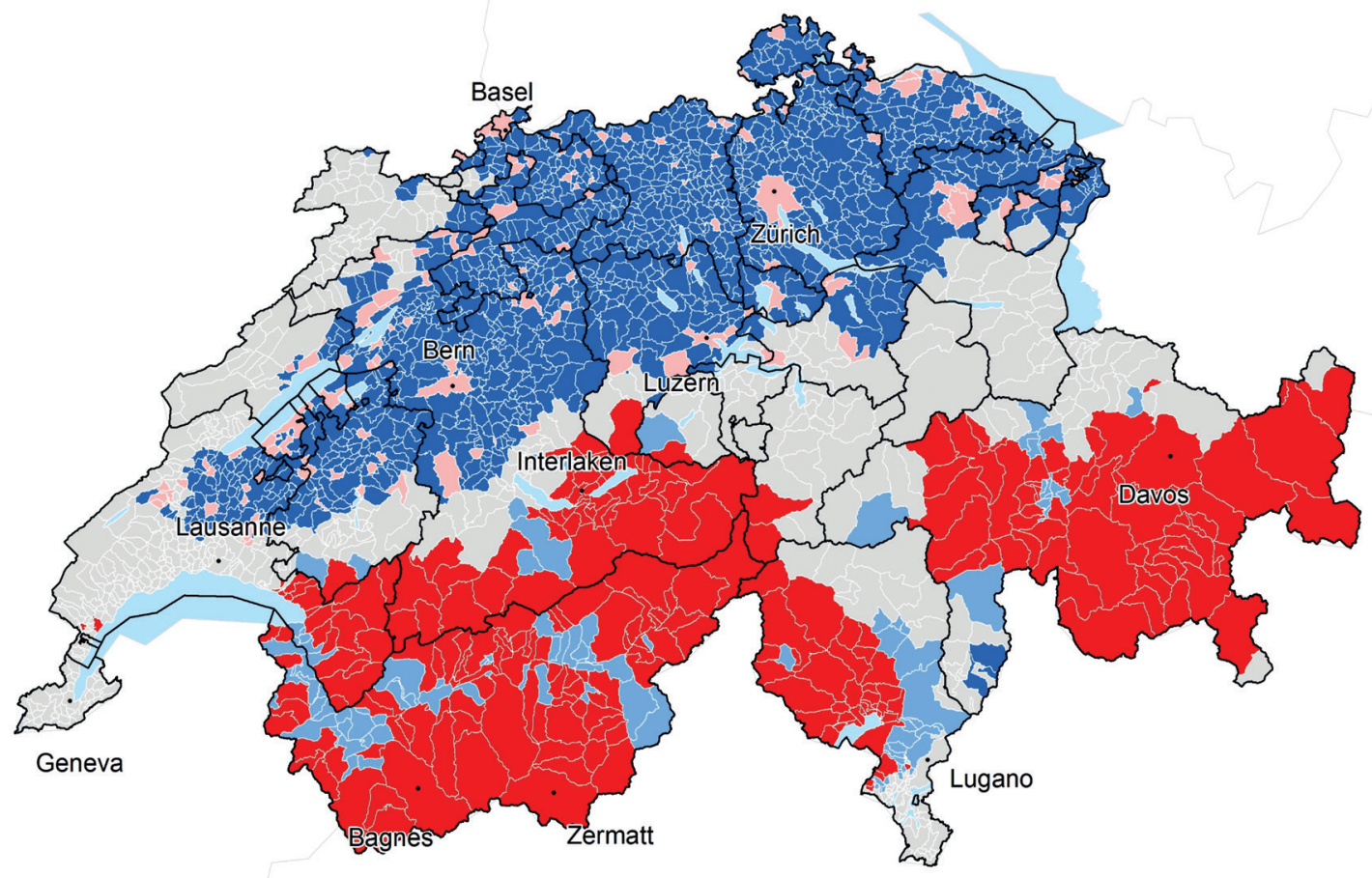

LISA cluster map (Type of spatial association):

Not significant
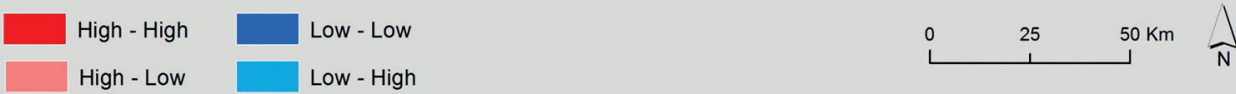

Fig. 4: Map of local Moran's spatial autocorrelation indicator with the variable Airbnb listings per 1,000 homes by municipality

nicipalities with low values. Out of these, the cities of Zurich (14 Airbnb listings per 1,000 homes), Basel (23.2), Luzern (9.8) and Bern (7.4) stand out. Only one High-High cluster has been detected in the northern part of the Alps. However, in this case, the Alps act as a connectivity element with the southern part and not as a barrier, because this cluster extends through the Valais canton as far as the west of the Ticino canton. Hence, as shown in Table

In our case, the results of the global indicator have pointed to a clustered distribution of the Airbnb listings per 1,000 housing units (Moran's $\mathrm{I}=0.282 ; \mathrm{p}<0.001 ; \mathrm{z}$ value $=74.069$ ). the Valais canton and Ascona (27.2) and Brissago (19.8) in the Ticino canton are some of the higher ratio municipalities in this cluster. Moreover, in southeast Switzerland there is an important HighHigh cluster made up of 52 municipalities in the Grisons canton, with Davos (38.3), St. Moritz (48.4) and $\operatorname{Vaz}$ (28.2) as some of the municipalities with greater indicator values. In line with the estimates by NicoD et al. (2007) about the Swiss regions with greatest potential for the expansion of holiday rentals, the results obtained point to Valais, Grisons, Bern and Ticino as the regions with the highest concentration of Airbnb listings. 
Tab. 4: Average value of Airbnb listings per 1,000 housing units per cluster and per canton

\begin{tabular}{|c|c|c|c|c|c|c|}
\hline Canton & No Sig. & High-High & Low-Low & Low-High & High-Low & Total \\
\hline Argovie & & & $1,5(200)$ & & $8,4(12)$ & $1,7(212)$ \\
\hline Appenzell Rhodes int. & $5,4(1)$ & & $1,8(4)$ & & $6.0(1)$ & $2,6(6)$ \\
\hline Appenzell Rhodes ext. & $4,6(1)$ & & 3,2 (13) & & $6,5(6)$ & $3,8(20)$ \\
\hline Berne & $3,8(41)$ & $26,3(41)$ & $1,7(231)$ & $4,1(4)$ & $7,7(30)$ & $5,8(347)$ \\
\hline Bâle Campagne & $0,6(6)$ & & $3,0(70)$ & & $6,7(10)$ & $3,4(86)$ \\
\hline Bâle Ville & & & $4,4(2)$ & & $23,2(1)$ & $21,4(3)$ \\
\hline Fribourg & $5,6(29)$ & $20,3(1)$ & $2,5(90)$ & $5,1(2)$ & $8,1(14)$ & $3,7(136)$ \\
\hline Genève & $13,3(45)$ & & & & & $13,3(45)$ \\
\hline Glaris & $3,2(3)$ & & & & & $3,2(3)$ \\
\hline Grisons & $10,4(39)$ & $28,1(52)$ & $1,7(2)$ & $1,5(15)$ & & $18,7(108)$ \\
\hline Jura & $3,0(47)$ & & $2,0(8)$ & & & $2,9(55)$ \\
\hline Lucerne & $6,4(4)$ & $11,5(1)$ & $1,96(71)$ & & $9,9(7)$ & $4,3(83)$ \\
\hline Neuchâtel & $2,5(17)$ & & 3,0 (12) & & $5,9(2)$ & $3,4(31)$ \\
\hline Nidald & $3,1(10)$ & & $1,08(1)$ & & & $2,8(11)$ \\
\hline Obwald & $6,5(5)$ & $9,2(1)$ & & $2,6(1)$ & & $6,3(7)$ \\
\hline Saint-Gall & $6,0(21)$ & & $2,1(51)$ & & $8,0(5)$ & $3,1(77)$ \\
\hline Schaffhouse & & & 2,2 (21) & & $13,0(5)$ & $2,5(26)$ \\
\hline Soleure & $3,0(1)$ & & 1,4 (99) & & $11,2(9)$ & 2,0 (109) \\
\hline Schwyz & 2,5 (13) & & 2,2 (13) & & $8,4(4)$ & $3,0(30)$ \\
\hline Thurgovie & & & $1,5(71)$ & & $7,7(9)$ & $2,0(80)$ \\
\hline Ticino & $6,5(56)$ & $14,6(36)$ & & 2,2 (23) & & $7,9(115)$ \\
\hline Uri & 2,9 (18) & $12,4(2)$ & & & & $3,1(20)$ \\
\hline Vaud & 7,7 (179) & $15,6(22)$ & $1,4(82)$ & $2,7(6)$ & $10,4(20)$ & $8,3(309)$ \\
\hline Valais & & $37,7(83)$ & & $3,11(43)$ & & $25,2(126)$ \\
\hline Zug & & & $2,2(10)$ & & $5,7(1)$ & $3,1(11)$ \\
\hline Zurich & & & 2,3 (158) & & $13,7(8)$ & $5,9(166)$ \\
\hline Total & 7,7 (536) & $26,9(239)$ & 2,0 (1209) & $2,8(94)$ & $12,8(144)$ & $7,4(2222)$ \\
\hline
\end{tabular}

Note: number of municipalities in brackets

\subsection{Determinants of the Airbnb spatial clustering}

The results of the regressions, presented in Table 5, show that all the variables included in the model specifications are statistically significant at $1 \%$. The results clearly highlight that the Airbnb concentration is higher in areas attractive to tourists and with pre-established tertiary activity, in general, particularly tourism activity. In this vein, the results pinpoint the municipalities with a higher population percentage in the tertiary sector as those with a higher presence of Airbnb listings. Meanwhile, those municipalities with a higher population percentage working in the first economic sector tend to have lower or nonexistent Airbnb listings. In the same way, from the results, it is possible to appreciate a positive association of the number of hotels and the average number of rooms per hotel with the dependent variable. In this sense, in line with other researches (Eugenio-Martin et al. 2019; Gutiérrez et al. 2017), an overlay between the hotel supply and the Airbnb supply has been identified. Furthermore, the results showcase a negative coefficient for the variable related to the distance to the nearest ski resort. This means that the closer the municipalities are to the ski and mountain resorts, the higher the number of Airbnb listings offered. At the same time, a higher Airbnb concentration is also found in larger, densely populated areas, which, apart from the mountain resorts, are leading leisure and tourism destinations. 
Tab. 5: Results of the NBM

\begin{tabular}{|c|c|c|c|c|c|c|}
\hline & \multicolumn{3}{|c|}{$1^{\text {st }}$ model } & \multicolumn{3}{|c|}{$2^{\text {nd }}$ model } \\
\hline & $\begin{array}{c}\beta \\
\text { (Standard } \\
\text { deviation) } \\
\end{array}$ & Standardised $\beta$ & VIF & $\begin{array}{c}\beta \\
\text { (Standard } \\
\text { deviation) }\end{array}$ & Standardised $\beta$ & VIF \\
\hline Intercept & $\begin{array}{c}1.0118 \\
(0.1474)\end{array}$ & & & $\begin{array}{c}1.2235 \\
(0.1495)\end{array}$ & & \\
\hline $\begin{array}{l}\text { Distance to nearest ski } \\
\text { resort }(\mathrm{km})\end{array}$ & $\begin{array}{l}-0.0216 \\
(0.0022)\end{array}$ & -0.2636 & 1.0579 & $\begin{array}{l}-0.0269 \\
(0.0022)\end{array}$ & -0.3283 & 1.0682 \\
\hline Second homes & $\begin{array}{c}0.0009 \\
(0.0001)\end{array}$ & 0.8009 & 1.2076 & & & \\
\hline Number of hotels & & & & $\begin{array}{c}0.0577 \\
(0.0055)\end{array}$ & 0.3742 & 1.2619 \\
\hline $\begin{array}{l}\text { Average number of rooms } \\
\text { per hotel }\end{array}$ & $\begin{array}{c}0.0172 \\
(0.0019)\end{array}$ & 0.2986 & 1.3044 & $\begin{array}{c}0.0192 \\
(0.0055)\end{array}$ & 0.3337 & 1.3129 \\
\hline $\begin{array}{l}\text { Airbnb listings offered per } \\
\text { multi-hosts }(\%)\end{array}$ & $\begin{array}{c}0.0269 \\
(0.0023)\end{array}$ & 0.2992 & 1.1269 & $\begin{array}{c}0.0386 \\
(0.0025)\end{array}$ & 0.4299 & 1.1375 \\
\hline $\begin{array}{l}\text { Employed population in the } \\
1 \text { st sector }(\%)\end{array}$ & $\begin{array}{l}-0.0156 \\
(0.0023)\end{array}$ & -0.2656 & 2.0136 & $\begin{array}{l}-0.0176 \\
(0.0023)\end{array}$ & -0.3009 & 2.0136 \\
\hline $\begin{array}{l}\text { Employed population in the } \\
\text { 2nd sector }(\%)\end{array}$ & \multicolumn{3}{|c|}{ Reference category } & \multicolumn{3}{|c|}{ Reference category } \\
\hline $\begin{array}{l}\text { Employed population in the } \\
\text { 3rd sector }(\%)\end{array}$ & $\begin{array}{c}0.0144 \\
(0.0018)\end{array}$ & 0.2202 & 1.8130 & $\begin{array}{c}0.0154 \\
(0.0018)\end{array}$ & 0.2975 & 1.8094 \\
\hline Thinly populated & $\begin{array}{l}-0.3668 \\
(0.0724)\end{array}$ & -0.1832 & 2.4501 & $\begin{array}{l}-0.5826 \\
(0.0772)\end{array}$ & -0.2910 & 2.4274 \\
\hline Intermediately populated & $\begin{array}{l}-0.2991 \\
(0.0769)\end{array}$ & -0.1310 & 1.7872 & $\begin{array}{l}-0.5032 \\
(0.0724)\end{array}$ & -0.2204 & 1.7717 \\
\hline Densely populated & \multicolumn{3}{|c|}{ Reference category } & \multicolumn{3}{|c|}{ Reference category } \\
\hline Goodness of fit indicators & \multicolumn{3}{|c|}{$\begin{array}{l}\text { AIC: 11,071.9; BIC:11,123.3; } \\
\text { Log-Likelihood: -5.526.9 }\end{array}$} & \multicolumn{3}{|c|}{$\begin{array}{l}\text { AIC: 11,357.5; BIC: 11,417.8; } \\
\text { Log-Likelihood: -5,669.7 }\end{array}$} \\
\hline
\end{tabular}

Note: All coefficients are statistically significant at $1 \%(\mathrm{p}<0.01)$

The explanatory variable with higher incidence has been the number of second homes. In fact, the model specification that includes this indicator as explanatory variable presents better goodness of fit indicators. This association is particularly relevant for two reasons. First, as predicted by NiCOD et al. (2007), new forms of online platforms, such as Airbnb, have helped to increase the visibility and cohesion of the high number of holiday homes in Switzerland. Second, there are signs that the Swiss tourism development model is transitioning to the "warm beds" model after the implementation of the second homes regularization initiative (CuIvaz 2013). Finally, a positive incidence has been detected with the percentage of listings offered by Airbnb multi-hosts. It supports the hypothesis that the multi-hosts are concentrating their Airbnb supply in areas with higher potential for generating profit (Eugenio-Martin et al. 2019; Yrigoy 2018)

Overall, the results support our research hypotheses about Airbnb's spatial distribution in Switzerland. Airbnb tends to be concentrated both in densely populated areas and alpine regions. The accommodation offered on this platform is overlaying and complementing the hotel supply. It is expanding towards municipalities where the potential demand is higher. In this regard, multi-hosts are seeing this as an opportunity to expand their offers in the country, and they are doing so not only in big cities, but also in places with a high presence of second homes and holiday homes.

\section{Discussion and conclusion}

This study has revealed the spatial distribution of Airbnb accommodation in Switzerland and has identified the determinants of its territorial logic. Applying the Local Moran's spatial autocorrelation indicator has revealed a prominent division between the northern and southern parts of the country. This confirms the first research hypothesis about the existence of clusterings of Airbnb listings in specific areas of the country.

Subsequently, the development of the negative binomial model has revealed noteworthy results and has allowed us to support the hypotheses about the 
possible factors influencing the distribution of Airbnb listings. The number of Airbnb short-term rentals per municipality is positively related to the size of the city, and its importance as a leisure tourism destination. We have detected that the Airbnb offer is spatially concentrated in municipalities with a higher number of hotels and also a greater average of rooms per hotel. The presence of second homes has been the most important factor in explaining Airbnb's spatial distribution in Switzerland. These results are in line with those obtained in previous researches (GUTIÉRREZ et al. 2017; AdAmiak et al. 2019), which demonstrated that Airbnb accommodation is spatially acting as a competitor for the traditional accommodation supply, while at the same time expanding its offer to other areas with potential for profiteering. Since the platform enables the commercialisation of private second homes (Adamiak 2018; Adamiak et al. 2019), Airbnb listings are expanding the accommodation supply, indistinctly, in both areas, with an important accommodation offer and an underdeveloped offer (CVELBAR and Dolnicar 2017; Gutierrez et al. 2017). In this regard, the presence of Airbnb listings in alpine tourist regions, such as the south of the Bern canton and Valais in general, is remarkable. Both private home owners and real estate agencies see the platform as an opportunity to avail of their assets, especially in highly attractive tourist territories. Our results showed that those areas with a higher number of Airbnb listings have higher relative values of short-term rentals offered by multi-hosts. This has three main implications. First, it means that investors and owners are interested in offering tourist accommodations in those areas with higher potential for extracting rents from the housing market (EugENIO-MARTIN et al. 2019; YrigoY 2018). Second, it implies that Airbnb is evolving towards professionalization, and acts as a new distribution channel for existing accommodation (ADAMIAK 2018). Hence, owners of holiday homes have perceived Airbnb as an opportunity to increase their visibility among tourists looking for accommodation (NICOD et al. 2007). And third, it seems that our results are signalling towards a potential conversion and transitioning from the "construction tourism" model to the "service tourism" model (CuIvaz 2013).

The results of this article are particularly valuable from a geographical perspective, as they shed some light on the fact that territorial characteristics are key to understanding the logic behind the growth of Airbnb. Despite this, mention has to be made of the potential limitations of the interpretation of the data used in this study. From the data available, it was not possible to distinguish the nature of the Airbnb supply, differentiating between tourist apartments, second homes or homes taken from the housing market. However, the results have shown the number of second homes as the most important variable in explaining the higher presence of short-term rentals. The availability of historical data could be especially useful for complementing this study, by analysing how the Airbnb supply has been modelled from its creation to current times, detecting trends and dynamics in its spatial diffusion. Therefore, further research is needed not only on a national scale, but also on other territorial scales, where the impact of the increasing number of Airbnb listings on both the housing and tourism markets can be analysed. In fact, analysing the distribution in attractive tourist alpine areas and urban areas may help to design and plan policies to avoid or mitigate potential gentrification processes, and to improve the marketing strategies for traditional accommodation. In this vein, another interesting complementary analysis would be to analyse Airbnb's impact on the hotel industry's performance, by analysing the evolution of prices and revenues. Some researches state that the professionalization of the Airbnb platform is affecting the performance of high-end hotels (LI and SRIVASAN 2019), while other studies conversely state that Airbnb seems to compete against low-end hotels (KOH and KING 2017; FANG et al. 2016).

\section{Acknowledgements}

Research funded by the Spanish Ministry of Science, Innovation and Universities [CSO201782156-R], the AEI/FEDER,UE, the Department of Research and Universities of the Catalan Government [2017SGR22], the Public Administration School of Catalonia [2018 EAPC 00002], and the Spanish Ministry of Education and Professional Formation [Doctoral Research Grant FPU15/06947 - Formación de Profesorado Universitario].

\section{References}

AbDar, M. and YeN, N. Y. (2017): Understanding regional characteristics through crowd preference and confidence mining in P2P accommodation rental service. In: Library Hi Tech, 35(4), 521-541. https://doi.org/10.1108/LHT01-2017-0030

ADAMIAK, C. (2018): Mapping Airbnb supply in European cities. In: Annals of Tourism Research, 71(2), 67-71. https://doi. org/10.1016/j.annals.2018.02.008 
Adamiak, C.; Szyda, B.; Dubownik, A. and García-Álvarez, D. (2019): Airbnb offer in Spain - spatial analysis of the pattern and determinants of its distribution. In: ISPRS International Journal of Geo-Information 8 (3), 155. https://doi.org/10.3390/ijgi8030155

ANSELIN, L. (1995): Local indicators of spatial association-LISA. In: Geographical Analysis, 27 (2), 93-115. https:// doi.org/10.1111/j.1538-4632.1995.tb00338.x

Boros, L.; Dudás, G.; KovalcsiK, T.; Papp, S. and Vida, G. (2018): Airbnb in Budapest : analysing spatial patterns and room rates of hotels and peer-to-peer accomodations. In: GeoJournal of Tourism and Geosites 21 (1), 26-38.

Bulchand-Gidumal, J.; Melián-González, S. and LÓpez-VALCÁrCEL, B. G. (2019): Is the sharing economy for all? An answer based on neighbourhoods, types of hosts, and user complaints. In: Pesonen, J. and NeIDHARDT, J. (eds): Information and communication technologies in tourism 2019. Cham, 55-66. https://doi. org/10.1007/978-3-030-05940-8_5

Cameron, A. C. and Trivedi, P. K. (2010): Microeconometrics using stata. College Station.

Cesarani, M. and Nechita, F. (2017): Tourism and the sharing economy. An evidence from Airbnb usage in Italy and Romania. In: Symphonya: Emerging Issues in Management 3, 32-47.

Choi, K.-H.; Joohyun, J.; Suyeol, R.; Su-Do, K. and SeongMin, Y.. (2015): The relationship between Airbnb and the hotel revenue: in the case of Korea. In: Indian Journal of Science and Technology 8 (26). https://doi. org/10.17485/ijst

Curvaz, C. (2013): Acceptance of the initiative on second homes: emergence of a new development model for Swiss winter sports resorts? In: Journal of Alpine Research | Revue de Géographie Alpine. https://doi. org/10.4000/rga.2274

Cócola GANT, A. (2016): Holiday rentals: the new gentrification battlefront. In: Sociological Research Online 21 (3), 1-9. https://doi.org/10.5153/sro.4071

Coyle, D. and Yu-Cheong, T. (2017): Understanding AirBnB in fourteen European cities. In: Industrielle, I. d'Economie (ed.) Tenth IDEI-TSE-IAST conference on the economics of intellectual property, software and the internet, Toulouse, France. https://www.lcii.eu/wp-content/uploads/2017/03/Yeung-Understanding-AirBnB-in-Fourteen-European-Cities-v4.1-1.pdf

Cvelbar, L. K. and Dolnicar, S. (2017): Filling infrastructure gaps. In: Dolnicar, S. (ed.):Peer-to-peer accommodation networks. Oxford, 98-108. https://doi. org/10.23912/9781911396512-3607

Dogru, T.; Mody, M. and Suess, C. (2018): Adding evidence to the debate: quantifying Airbnb's disruptive impact on ten key hotel markets. In: Tourism Management 72, 27 38. https://doi.org/10.1016/j.tourman.2018.11.008
Eugenio-Martin, J.; Cazorla-Artiles, J. M.; GonzÁlez-MarTEL, C. (2019): On the determinants of Airbnb location and its spatial distribution. In: Tourism Economics. https://doi. org/10.1177/1354816618825415

FANG, B.; YE, Q. and LAW, R. (2016): Effect of sharing economy on tourism industry employment. In: Annals of Tourism Research 57, 264-267. https://doi.org/10.1016/j.annals.2015.11.018

FINCK, M. and Ranchord, S. (2016): Sharing and the city. In: Vanderbilt Journal of Transnational Law 49 (5), 1299-1369.

Gravari-Barbas, M. and Guinand, S. (2017): Addressing tourism-gentrification processes in contemporary metropolises. In: Tourism and Gentrification in Contemporary Metropolises: International Perspectives. https://doi. org/10.4324/9781315629759

Gunter, U. (2018): What makes an Airbnb host a superhost? Empirical evidence from San Francisco and the Bay Area. In: Tourism Management 66, 26-37. https://doi. org/10.1016/j.tourman.2017.11.003

Gunter, U. and ÖNDER, I. (2017). Determinants of Airbnb demand in Vienna and their implications for the traditional accommodation industry. Tourism Economics 24 (3), 270 293. https://doi.org/10.1177/1354816617731196

Gutierrez, J.; García-Palomares, J. C.; Romanillos, G. and Salas-Olmedo, M. H. (2017): The eruption of Airbnb in tourist cities: Comparing spatial patterns of hotels and peer-to-peer accommodation in Barcelona. In: Tourism Management 62, 278-291. https://doi.org/10.1016/j. tourman.2017.05.003

GutTentag, D. (2015): Airbnb: disruptive innovation and the rise of an informal tourism accommodation sector. In: Current Issues in Tourism, 18 (12), 1192-1217. https:/ / doi.org /10.1080/13683500.2013.827159

Hamari, J.; Mimmi, S. and UkKonen, A. (2015): Writing information literacy assessment plans: a guide to best practice. In: Journal of the Association for Information Science and Technology 67 (9), 2047-2059.

Heo, C. Y.; Blal, I. and ChoI, M. (2019): What is happening in Paris? Airbnb, hotels, and the Parisian market: a case study. In: Tourism Management 70, 78-88. https://doi. org/10.1016/j.tourman.2018.04.003

Horn, K. and Merante, M. (2017): Is home sharing driving up rents? Evidence from Airbnb in Boston. In: Journal of Housing Economics 38, 14-24. https://doi.org/10.1016/j. jhe.2017.08.002

IOANNIDES, D.; RÖSLMAIER, M. and VAN DER ZEe, E. (2018): Airbnb as an instigator of "tourism bubble" expansion in Utrecht's Lombok neighbourhood. In: Tourism Geographies. https://doi.org/10.1080/14616688.2018.1454505

JEFFERSON-JONES, J. (2014): Airbnb and the housing segment of the modern sharing economy: are short-term rental restrictions an unconstitutional taking. In: Hastings Constitutional Law Quarterly 42, 557-576. 
KoH, E. and KING, B. (2017): Accommodating the sharing revolution: a qualitative evaluation of the impact of Airbnb on Singapore's budget hotels. In: Tourism Recreation Research 42, 409-421. https://doi.org/10.1080 /02508281.2017.1314413

Larpin, B.; Mabillard, J.; Scaglione, M.; Favre, P. and Schegg, R. (2019): An analysis of regional developments of Airbnb in Switzerland: insights into growth patterns of a P2P platform. In: Pesonen, J. and NeidHARdt, J. (eds) Information and communication technologies in tourism. Cham, 92103. https://doi.org/10.1007/978-3-030-05940-8_8

LEE, D. (2016): How Airbnb short-term rentals exacerbate Los Angeles's affordable housing crisis: analysis and policy recommendations. In: Harvard Law \& Policy Review 10 (1), 229-253.

Li, H, and Srinivasan, K. (2019): Competitive dynamics in the sharing economy: an analysis in the context of Airb$\mathrm{nb}$ and hotels. In: Marketing Science 38 (3). https://doi. org/10.1287/mksc.2018.1143

McCullagh, P. and Nelder, J.A. (1989): Generalized linear models. London. https://doi.org/10.1007/978-1-48993242-6

Nicod, P., Mungall, A. and Henwood, J. (2007): Self-catering accommodation in Switzerland. In: International Journal of Hospitality Management 26 (2), 244-262. https:/ / doi. org/10.1016/j.ijhm.2006.10.004

Novy, J. (2017): The selling (out) of Berlin and the de- and re-politicization of urban tourism in Europe's "Capital of Cool". In: Colomb, C. and Novy, J. (eds): Protest and resistance in the tourist. London, 52-72.

Oskam, J. and Boswijk, A. (2016): Airbnb: the future of networked hospitality businesses. In: Journal of Tourism Futures 2 (1), 22-42. https://doi.org/10.1108/JTF-112015-0048

Quattrone, G.; Greatorex, A. and Quercia, D.; Capra, L. and Musolesi, M. (2018): Analyzing and predicting the spatial penetration of Airbnb in U.S. cities. In: EPJ Data Science 7: 31. https://doi.org/10.1140/epjds/s13688018-0156-6

Roelofsen, M. (2018): Exploring the socio-spatial inequalities of Airbnb in Sofia, Bulgaria. In: Erdkunde 72 (4), 312-327. https://doi.org/10.3112/erdkunde.2018.04.04

Strommen-Bakhtiar, A. and Vinogradov, E. (2019): The adoption and development of Airbnb services in Norway. In: International Journal of Innovation and Digital Economy 10, 28-39. https://doi.org/10.4018/ IJIDE.2019040102

Swiss Tourism Federation (2019): Swiss tourism in figures 2018: structure and industry data. https://www.stv-fst.ch/ sites/default/files/2019-07/STiZ_2018_EN_Web.pdf

Tobler, A. W. R. (1970): A computer movie simulating urban growth in the Detroit region. In: Economic Geography 46 (Sup (1)), 234-240. https:/ / doi.org/10.2307/143141
Tissot, L. (2002): El turismo en Suiza o el advenimiento de un modelo de excelencia (siglos XIX y XX). In: Historia Contemporánea 25, 83-100.

Wachsmuth, D. and Weisler, A. (2018): Airbnb and the rent gap: gentrification through the sharing economy. In: Environment and Planning A: Economy and Space 50 (6), 1147-1170. https://doi.org/10.1177/0308518X18778038

YrigoY, I. (2017): Airbnb en Menorca: ¿Una nueva forma de gentrificación turística?: Localización de la vivienda turística, agentes e impactos sobre el alquiler residencial. In: Scripta Nova 21. https://doi.org/10.1344/sn2017.21.18573

- (2019): Rent gap reloaded: Airbnb and the shift from residential to touristic rental housing in the Palma Old Quarter in Mallorca, Spain. In: Urban Studies 56 (13), 2709-2726. https://doi.org/10.1177/0042098018803261

Zervas, G.; Proserpio, D. and Byers,J. (2017): The rise of the sharing economy: estimating the impact of Airbnb on the hotel industry. In: Journal of Marketing Research 54, 687705. https://doi.org/10.1509/jmr.15.0204

Authors

Antoni Domènech ORCID iD: 0000-0002-1881-6679 Universitat Rovira i Virgili Department of Geography Campus Vila-seca C/ Joanot Martorell, 15 43480 Vila-seca Spain antoni.domenech@urv.cat

Prof. Blaise Larpin ORCID iD: 0000-0002-0068-2289 Prof. Dr. Roland Schegg ORCID iD: 0000-0002-7738-4191

Prof. Dr. Miriam Scaglione ORCID iD: 0000-0002-0930-4014 University of Applied Sciences and Arts Western Switzerland

Institute of Tourism

Rte de la Plaine 2

PO box 80

3960 Sierre

Switzerland

blaise.larpin@hevs.ch roland.schegg@hevs.ch miriam.scaglione@hevs.ch 